\title{
THE GROWTH OF SELECTED CENTRAL AND EASTERN EUROPEAN ECONOMIES WITH REFERENCE TO THE GLOBAL COMPETITIVENESS INNOVATION FACTOR
}

\section{PIOTR SZKLARZ}

University of Szczecin, Faculty of Management and Economics of Services, POLAND

e-mail: piotr.szklarz@wzieu.pl

RECEIVED

ACCEPTED

JEL

CLASSIFICATION

KEYWORDS

ABSTRACT
10 December 2018

28 December 2018

030, 057

innovation, GDP growth, Central and Eastern European economies

Innovation is perceived as the key factor contributing to the economic prosperity of countries and regions. Endogenous growth models provide vast theoretical support for regarding technical progress as internal factor determining economic growth. The experience of developed countries proves positive impact of innovation on the growth of their GDP in the long term, on the other hand, many emerging economies search for the way of further transformation to support faster development. In this context, the analysis of innovation and business sophistication factor, as well as, GDP growth of selected emerging European economies, seems an interesting research area. The study's conclusions can contribute to the discussion of possible ways of further transformation of emerging economies of Central and Eastern Europe.

\section{Introduction}

In the current economic environment, as confirmed by economists and scientists, competitive advantage should be primarily associated with the innovation capacity and ability to continuously increase the level of innovation to achieve adequate efficiency (Perenc, Hołub-Iwan, 2011, p. 9). Economists and experts of Global Future Councils believe that new, rapidly developing technologies will further influence the way of production, 
goods transport, providing services, communication and cooperation. Opportunities and challenges caused by new technologies vast implementation will cause fundamental changes in global economy and will eventually create the fourth industrial revolution (Schwab, Davis, 2016, p. 10). These statements are based on the theories and models of economic growth, which are generally divided to exogenous and endogenous. Both categories include the factor of technological progress and innovation, however, they treat them differently. Exogenous growth models main assumption is that economy endeavors to long-term sustainable growth, the scale of which is determined by the external rate of technical progress. The most common in this group is so called Solow-Swan growth model. R. Solow refers to the theory of innovation introduced by J.A. Schumpeter and assumes that long-term economic growth is determined by three factors: labour resources, capital accumulation and technical progress, which is being treated as an external and major growth factor (Solow, 1954, pp. 65-94). On the opposite, endogenous growth models are based on different assumption. These models remain constitutive part of new growth theory, which perceives technical progress as a result of enterprises' investment decisions and rational consumers' choices. The rate of technical progress is therefore treated as an internal factor determining economic growth. One of the earliest attempts to perceive this progress as an endogenous factor was introduced with $\mathrm{K}$. Arrow's phenomenon of learning by doing (Arrow, 1962, pp. 155-173). The researchers further point to another factors of growth such as for example: knowledge and human capital (R. Lucas) or research and development investment (P. Romer) and explain how innovations allow continuous increase of wealth (Aghion, Howitt, 1992, pp. 323-351). In addition, economists point out that innovation not only allow the rise of productivity, but also contributes to economic growth by increasing diversity and quality of products and services, enhancing competitiveness as a result (Grossman, Helpman, 1991, p. 22). Innovation is therefore the major factor contributing to the economic prosperity of countries and regions. The experience of developed countries shows that it is crucial for the growth of economies in the long term (Janasz, 2010, p. 103). The purpose of this article is to verify whether similar conclusions also concern selected emerging economies of Central and Eastern Europe during recent five-year period.

\section{GCl methodology}

The world's broadest research on the competitiveness of economies of both developed and developing countries, as well as, the impact of innovation on its level, has been realized by economists related to the World Economic Forum for more than forty years. The competitiveness assessment is based on the main determinants improving productivity and enabling growth and economic prosperity of countries. The results of this research include 140 countries in the world and are published regularly in the form of Global Competitiveness Report. The summary parameter measured in these studies is the Global Competitiveness Index (GCl), which was originally based on the assumptions created by K. Schwab and developed by X. Sala-i-Martin. The index methodology was originally based on the theoretical background of economic growth theory developed by J. Sachs and supported by M. E. Porter researches on business competitiveness. Up-to-date $\mathrm{GCl}$ consists of 114 indicators gathered in twelve pillars, grouped in three main sub-indexes, which have major impact on the long-term growth and competitiveness of economies. The detailed components of the Global Competitiveness Index and sub-indexes are presented on Figure 1. 


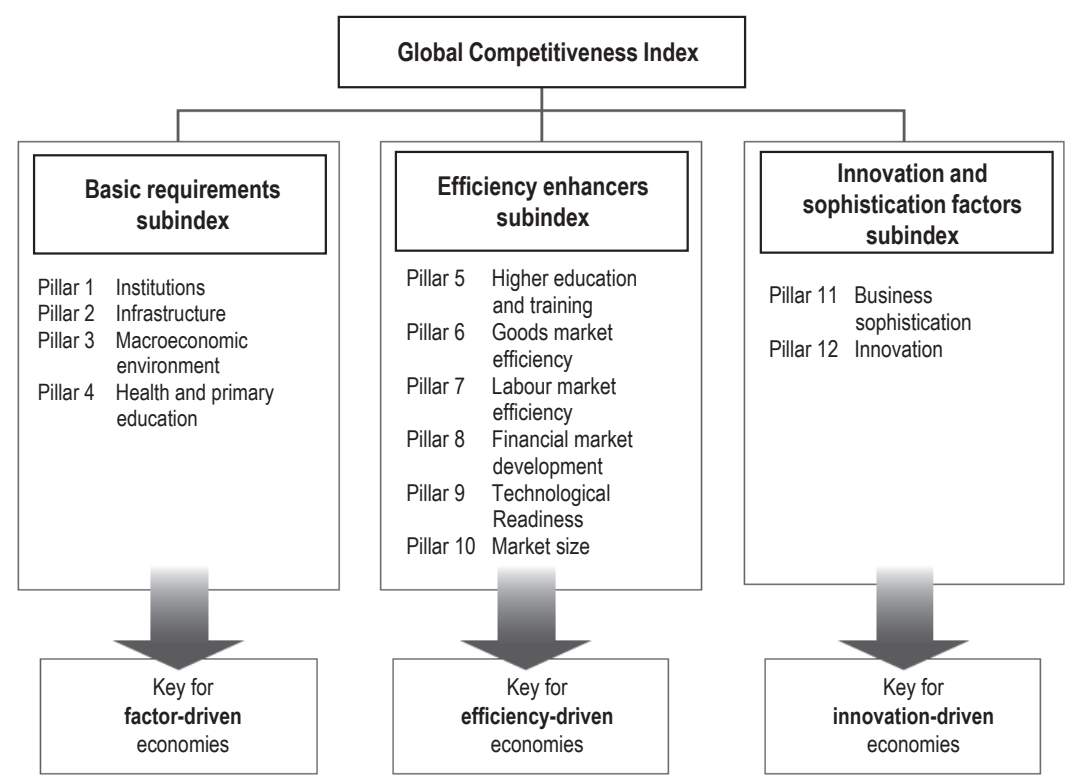

Figure 1. The detailed components of the Global Competitiveness Index and sub-indexes

Source: The Global Competitiveness Report 2017-2018 (2017), p. 12.

One of the three main sub-indexes consists of innovation and business sophistication factors. The following indicators are analyzed within innovation pillar: capacity for innovation, quality of scientific research institutions, company spending on research and development, university-industry collaboration in research and development, government procurement of advanced technology products, availability of scientists and engineers, Patent Cooperation Treaty patents (number of applications per million population). The following indicators are analyzed within business sophistication pillar: local supplier quantity, local supplier quality, state of cluster development, nature of competitive advantage, value chain breadth, control of international distribution, production process sophistication, extent of marketing and willingness to delegate authority. Both pillars define the total factor for innovation-driven economies. According to opinions of many excellent economists, contributors to the global competitiveness research, innovation is therefore one of the pillars of economies' competitiveness and thus the capacity to achieve productivity increase, as well as, long-term GDP growth.

\section{GCl innovation and sophistication factors in selected countries}

In order to verify the assumption of positive influence of innovation on long-term economic growth also among emerging economies, six Central and Eastern European countries were selected for five-year comparison. The selection was accomplished basing on the following criteria: emerging status with similar economy transformation track-record, European Union membership, affiliation to one group defined by EUROSTAT according to real GDP per capita (EUR 11,800-17,200 in 2017) and homogeneous geographical region of Central and Eastern Europe. Real GDP per capita within EUROSTAT methodology stands for total final output of goods and services produced by economy in certain period of time and is calculated for average population of specific year. 
The selected members of the group created basing on mentioned criteria are: Czech Republic, Estonia, Lithuania, Hungary, Poland and Slovakia. Global competitiveness index and sub-indexes for selected countries are scored between 1 to 7 points. The sub-index of innovation is additionally supported by the status of business sophistication, which includes cooperation within business sectors and suppliers. This approach is in line with the theory of open innovation (Chesbrough, 2006 and Chesbrough, Garman, 2012, pp. 46-56). The detailed information about total $\mathrm{GCl}$ and innovation and business sophistication sub-index scores in 2012 and 2017 for six selected countries are presented in Table 1.

Table 1. The detailed information about $\mathrm{GCl}$ and innovation and business sophistication sub-index scores for selected countries

\begin{tabular}{|c|c|c|c|c|}
\hline & Total GCI score 2012 & Total GCI score 2017 & $\begin{array}{l}\text { Innovation and business } \\
\text { sophistication score } 2012\end{array}$ & $\begin{array}{l}\text { Innovation and business } \\
\text { sophistication score } 2017\end{array}$ \\
\hline Czech Republic & 4.50 & 4.80 & 4.10 & 4.20 \\
\hline Estonia & 4.60 & 4.85 & 4.10 & 4.20 \\
\hline Lithuania & 4.40 & 4.60 & 3.80 & 4.00 \\
\hline Hungary & 4.30 & 4.30 & 3.70 & 3.50 \\
\hline Poland & 4.50 & 4.60 & 3.70 & 3.80 \\
\hline Slovakia & 4.10 & 4.30 & 3.50 & 3.80 \\
\hline
\end{tabular}

Source: own elaboration based on: https://ec.europa.eu/eurostat/tgm (2018).

The top three scores of total $\mathrm{GCl}$ in 2012 involving all partial sub-indexes were achieved by: Estonia, Poland and Czech Republic with the same score. In 2017 the top three belonged to: Estonia, Czech Republic, Lithuania and Poland with the same score. The top three scores of innovation and business sophistication sub-index scores in 2012 were achieved by: Czech Republic and Estonia with the same score, and Lithuania. In 2017 the top three remained the same. In 2017 all selected countries either improved, or maintained their GCl total scores in comparison to 2012. In 2017 five selected countries improved their innovation and business sophistication sub-index scores except for Hungary. Top three countries further improved their situation in relation to others within then group - the scores exceeded 4. The scores achieved by Lithuania and Poland are especially interesting for comparison. Although, in 2017 total GCl scores were on the same level, innovation and business sophistication sub-index score achieved by Lithuania was higher. It means that the score of other sub-indexes remaining keys for factor and efficiency-driven economies were on higher level for Poland.

In order to further analyse the essence of innovation and business sophistication differences among selected countries, the detailed indicators were taken into consideration. The detailed composition of innovation indicators for selected countries achieved in 2017 are presented on Figure 2.

The best scores for innovation capacity were achieved by Czech Republic and Estonia followed by Lithuania. The best score for quality of scientific research institutions was achieved by Estonia followed by Czech Republic. The best score for company spending on research and development was achieved by Czech Republic followed by Lithuania. The best score for university-industry collaboration in research and development was achieved by Lithuania followed by Czech Republic and Estonia. The best score for government purchase decisions for the procurement of advanced technology products was achieved by Estonia followed by Slovakia. The best score for availability of scientists and engineers was achieved by Estonia followed by Poland. The highest number 
of Patent Cooperation Treaty patents' applications per million population was achieved by Estonia followed by Hungary. The detailed composition of business sophistication indicators for selected countries achieved in 2017 are presented on Figure 3.

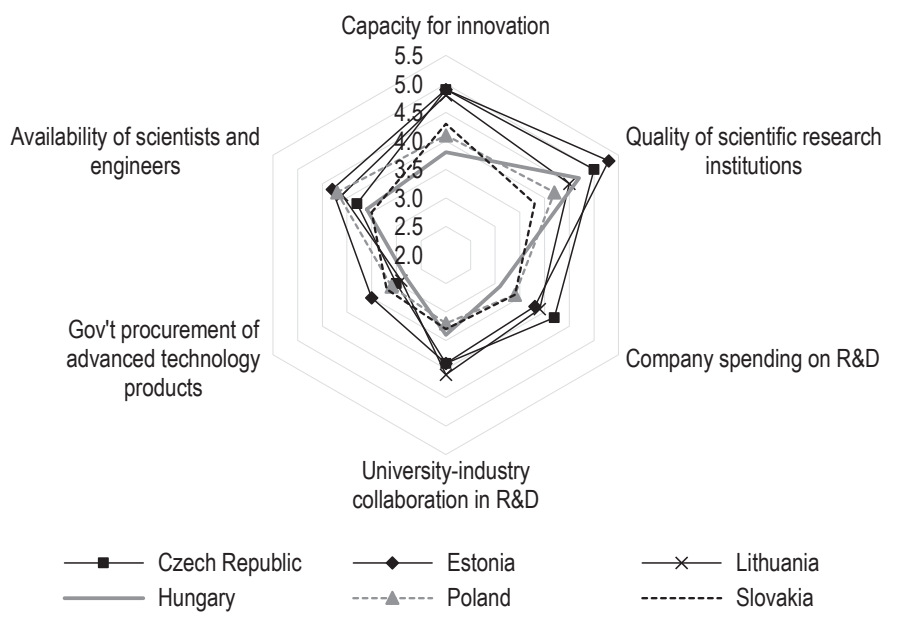

Figure 2. The detailed composition of innovation indicators scores for selected countries in 2017

Source: own elaboration based on The Global Competitiveness Report 2017-2018 (2017).

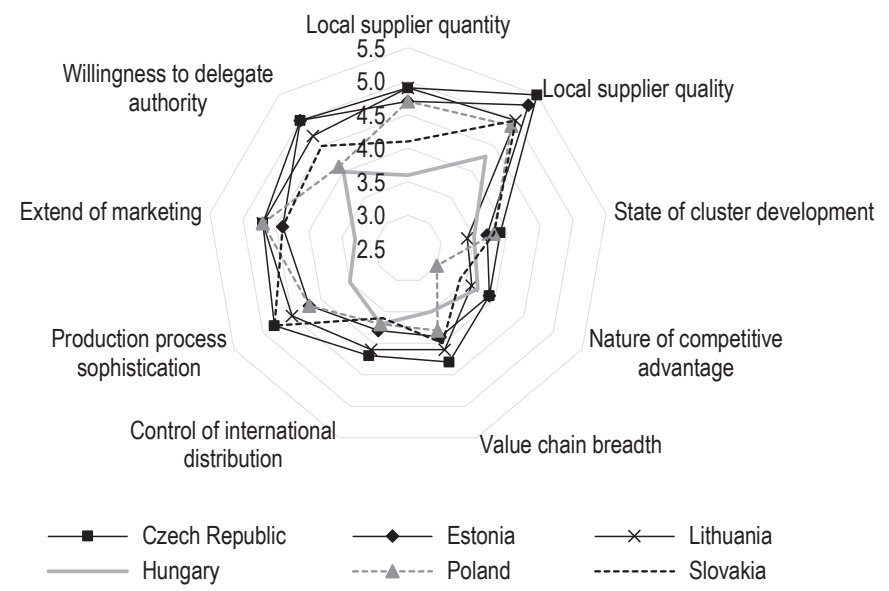

Figure 3. The detailed composition of business sophistication indicators scores for selected countries in 2017

Source: own elaboration based on The Global Competitiveness Report 2017-2018 (2017).

The best scores for local supplier quantity were achieved by Czech Republic and Lithuania. The best score for local supplier quality was achieved by Czech Republic followed by Estonia. The best score for state of cluster 
development was achieved by Czech Republic followed by Poland and Slovakia. The best scores for nature of competitive advantage were achieved by Czech Republic and Estonia. The best score for value chain breadth was achieved by Czech Republic followed by Lithuania. The best score for control of international distribution was achieved by Czech Republic followed by Lithuania. The best scores for production process sophistication were achieved by Czech Republic and Slovakia. The best scores for extend of marketing were achieved by Czech Republic, Lithuania and Poland. The best scores for willingness to delegate authority were achieved by Czech Republic, Estonia followed by Lithuania.

\section{GDP growth in selected countries}

Having verified the scores of both, total $\mathrm{GCl}$, innovation and business sophistication sub-index, the next step is to analyse gross domestic product growth in selected economies. In order to support comparable background for analyses, real GDP per capita calculated according to EUROSTAT methodology for the same period of time (2012-2017) was taken into consideration. One should additionally have in mind, that weighted score for total GCl index, according to World Economic Forum reporting methodology, includes diversities depended on the stage of economy development measured by GDP per capita. Real GDP per capita, as well as, its nominal and relative growth 2017 vs. 2012 for selected countries are presented on Table 2.

Tahle 2. Real GDP per capita (in EUR) nominal and relative growth 2017 vs. 2012 for selected countries

\begin{tabular}{|c|c|c|c|c|}
\hline & GDP per capita 2012 & GDP per capita 2017 & $\begin{array}{l}\text { GDP per capita nominal } \\
\text { growth } \\
\end{array}$ & $\begin{array}{c}\text { GDP per capita relative } \\
\text { growth }(\%)\end{array}$ \\
\hline Czech Republic & 15,100 & 17,200 & 2,100 & 13.9 \\
\hline Estonia & 12,500 & 14,600 & 2,100 & 16.8 \\
\hline Lithuania & 10,300 & 12,700 & 2,400 & 23.3 \\
\hline Hungary & 10,000 & 11,800 & 1,800 & 18.0 \\
\hline Poland & 10,000 & 11,800 & 1,800 & 18.0 \\
\hline Slovakia & 13,100 & 15,000 & 1,900 & 14.5 \\
\hline Average & 11,833 & 13,850 & 2,017 & 17.0 \\
\hline
\end{tabular}

Source: own elaboration based on: https://ec.europa.eu/eurostat/tgm (2018).

The highest nominal real GDP per capita growth in 2017 vs. 2012 was achieved by Lithuania followed by Czech Republic and Estonia. At the same time, the nominal growth achieved by these three countries exceeds average nominal growth level of EUR 2017 per capita by EUR 383 for Lithuania and EUR 83 in case of Czech Republic and Estonia. The remaining three countries achieved nominal growth levels as follows: EUR 117 below average for Slovakia and EUR 217 below average in case of Poland and Hungary. The highest relative real GDP per capita growth rate also belongs to Lithuania. The following countries relative growth rates should be perceived in relation to different basic GDP per capita levels achieved in 2012. 


\section{Conclusions}

Having analysed five-year development of scores of innovation and business sophistication sub-index, calculated according to Global Competitiveness Report methodology, and real GDP per capita, calculated according to EUROSTAT methodology, positive influence of innovation on the growth of emerging economies seems confirmed. The analysis was accomplished on selected Central and Eastern European countries belonging to one group, in terms of economy stage of development, measured by GDP per capita and also having similar transformation background. There are three group innovation leaders: two of them - Czech Republic and Estonia have confirmed leading, established position, the third - Lithuania has made the biggest progress in the group during five-year period. It is worth to underline that Lithuania achieved significant leading position in university-industry collaboration concerning research and development. At the same time, the economy growth measured by real GDP per capita for selected group of countries confirms leading position of Lithuania, both in nominal and relative growth. The subsequent results were achieved by Czech Republic and Estonia. It is important to notice, that the nominal GDP per capita growth of the leader was $19 \%$ higher than average for the group of countries. The nominal growth of both followers was $4 \%$ higher than the group average. The total scores of $\mathrm{GCl}$ index for Lithuanian and Polish economies were the same in 2017. It seems additional confirmation that the majority impact on long-term growth, even for smaller, emerging economies is determined by innovation.

\section{References}

Aghion, Ph., Howitt, P. (1992). A Model of Growth Through Creative Destruction. Econometrica, 60 (2), 323-351.

Arrow, K.J. (1962). The Economic Implications of Learning by Doing. The Review of Economic Studies, 29 (3), $155-173$.

Chesbrough, H.W. (2006). Open Business Models: How to Thrive in The New Innovation Landscape. Boston: Harvard Business School Press.

Chesbrough, H.W., Garman, A.R. (2012). Otwarta innowacyjność: recepta na trudne czasy. Boston: Harvard Business Review Press. Grossman, G.M., Helpman, E. (1991). Innovation and Growth in the Global Economy. Cambridge, Massachusetts: The MIT Press. https://ec.europa.eu/eurostat/tgm.

Janasz, K. (2010). Kapitał w finansowaniu działalności innowacyjnej przedsiębiorstw w Polsce, źródła i modele. Warszawa: Difin.

Perenc, J., Hołub-Iwan, J. (2011). Innowacje w rozwijaniu konkurencyjności firm. Znaczenie, wsparcie, przykłady zastosowań. Warszawa: C.H. Beck.

Schwab, K., Davis, N. (2018). Schaping the fourth industrial revolution. Geneva: World Economic Forum.

Solow, R.M. (1956). A Contribution to The Theory of Economic Growth. The Quarterly Journal of Economics, 70 (1), 65-94.

The Global Competitiveness Report 2017-2018 (2017). Geneva: World Economic Forum.

Cite this article aS: Szklarz, P. (2018). The growth of selected Central and Eastern European economies with reference to the global competitiveness innovation factor. European Journal of Service Management, 4 (28/2), 471-477. DOI: 10.18276/ejsm.2018.28/2-56. 